\title{
The Scenography of Shakespearománie I.-III. [The Shakespearomania Trilogy] Directed by Peter Scherhaufer at Goose on a String Theatre in Brno
}

Dagmar Inštitorisová

\begin{abstract}
The study of the Scenography for Shakespearománie I.-III. [Shakespearomania Trilogy] directed by Peter Scherhaufer at the Goose on a String Theatre in Brno is an analytical and poetological profiling of the three productions created within the project called SHAKESPEAROMÁNIE [Shakespearomania Trilogy], directed by Peter Scherhaufer, one of the most regarded Czechoslovak directors of Slovak origin, who is also a co-founder of the Goose on a String Theatre in Brno. The said productions are: Veličenstva Blázni - SHAKESPEAROMÁNIE I (1988) [Their Majesties' Fools - Shakespearomania Trilogy I], Lidé Hamleti - SHAKESPEAROMÁNIE II (1990) [The Hamlet Humans - Shakespearomania Trilogy II] and Člověk Bouře - SHAKESPEAROMÁNIE III (1993) [The Tempest Man - Shakespearomania Trilogy III]. The emphasis is not only on the scope of dramatic language used in the plays, but also on the development of some of their production and scenographic characteristics in a pretextual situation, their reception, and partly their place within the context of Scherhaufer's work. Special attention is paid to the prehistory of spatial analysis of dramatic texts - a method, which P. Scherhaufer used when preparing the project. The stage design of the productions within the project is interpreted primarily from the standpoint of semiotics and pretext.
\end{abstract}

\section{Keywords}

Peter Scherhaufer, project SHAKESPEAROMÁNIE I.-III. [Shakespearomania Trilogy], language, poetics, conventional signs, intertextuality, specifics of individual style, stage design, scenography 


\section{Introduction}

The project Shakespearománie I.-III. [Shakespearomania Trilogy] at the Goose on a String Theatre in Brno consists of three productions: Veličenstva Blázni - SHAKESPEAROMÁNIE I (1988) [Their Majesties' Fools - Shakespearomania Trilogy I], Lidé Hamleti - SHAKESPEAROMÁNIE II (1990) [The Hamlet Humans - Shakespearomania Trilogy II] and Člověk Bouře - SHAKESPEAROMÁNIE III (1993) [The Tempest Man - Shakespearomania Trilogy III], all directed by Peter Scherhaufer. ${ }^{1}$ The project was very fecund and non-traditional thanks to the development of Peter Scherhaufer's directing skills and style. He worked on the project alongside several other large-scale projects of the Goose on a String Theatre in Brno. He was involved in those projects not only as a director but also as a co-author with other renowned theatre professionals from the theatre and external experts, such as Eva Tálska, Petr Oslzlý, Zdisław Hejduk, Arnošt Goldflam, Josef Kovalčuk. From the beginnings of Shakespearománie I.-III. [Shakespearomania Trilogy] in 1984 until the premiere of the last piece in 1993, the PROJEKT 1985 (Scénické cútanie zo súćasnej literatúry národov Sovietskeho zväzu) [Project 1985 (Staged Reading from the Contemporary Literature of the Nations of the Soviet Union)] comprised eight productions. The project responded to the demands of a particular theatre audience for productions on contemporary and current topics. Furthermore, the Goose on a String Theatre staged the project called MIR CARAVANE - KARAVANA MIR (1989) and toured several European cities with it. In the East of Slovakia, the theatre hosted staged readings of the books written by local authors titled KEMU CE TREBA '91 [Who Needs You '91]. It comprised seven productions, and the Goose on a String Theatre also hosted a project of the theatre journal Rozrazil (since 1988), which was a response to the current social and political situation, including the Velvet Revolution.

Compared to other projects, the uniqueness of SHAKESPEAROMÁNIE [the Shakespearomania Trilogy] is not only in the topic, but also in the fact that all the productions were set on the same stage in Procházka Hall, House of Arts, Brno. In dramaturgical terms, it is important in merging various translations of the play (The Hamlet Humans); from the perspective of Scherhaufer's directional style it is a project that brought together its view of the theater and society at large before the Velvet Revolution in 1989 with the current view of the period immediately thereafter, or in how the language of postmodernism, namely intertextuality, combined with the stage design vision of the three stage artists into particular solutions. The above and other significant aspects of the trilogy will be reflected upon later in this analysis.

1 The author cooperated with the Centre for Experimental Theatre (CED), a state-funded institution of the City of Brno when researching the material for the proposed study. 


\section{The Visual Genesis and Other Developments in the Project}

SHAKESPEAROMÁNIE [the Shakespearomania Trilogy] has a rich and fascinating history in certain aspects. Scherhaufer (SCHERHAUFER 1996) and dramaturg of the project Peter Oslzlý (OSLZLÝ and SCHERHAUFER 1988) have repeatedly said that the project came to life in 1984 based on a large-scale audience poll. The demand for Shakespeare productions voiced by the audience was quite common throughout the 1980s (OSLZLÝ 1999, ${ }^{2}$ 1988). ${ }^{3}$

The project was officially launched in 1987, but another project was underway Divadlo v pohybe III. [Theatre in Motion III] after Scherhaufer and Oslzlý found their answers to the core issues of the potential meanings of Shakespeare's plays in the original periods, in the present, as well as for Shakespeare himself. The first thirtyseven rehearsals were devoted to the allusive interpretation of thirty-seven Shakespeare plays, i.e. one text was rehearsed each day. Scherhaufer's original idea was to set up a company called The Shakespeare Factory to transform Shakespeare's plays into theatre productions, but it didn't come to fruition (KOHUTOVÁ 1996: 66). The theatre group began to rehearse the plays chronologically according to their year of origin because Scherhaufer wanted to understand how Shakespeare developed his understanding of the world in his plays. He gradually established a range of topics, situations, acts, exchanges, which was interesting to everyone, and the future script was developed based on how those elements were created. The improvised rehearsals were also interesting for another reason. The actors had different versions of the translations and, because there were some misunderstandings in the meanings of specific exchanges, they had to find different ways to blend the translations into one sensible unit. Since the rehearsals were held in improvised conditions only using the stage props available in the theatre storage room, the creators of the productions decided that the scenography should be based on the typical Shakespearean thrust stage open on three sides, with the audience sitting around it. Only a small number of props were to be used, as was the case in Shakespeare's times. The decision on how to stage the plays was also based on various catalogues, such as the catalogue of stages and elements of fear, catalogue of death and madness, catalogue of folk dialogues, catalogue of servants and lords, Falstaff's catalogue, catalogue of women, catalogue of negatives, theatre catalogue and catalogue of the bourgeoisie. ${ }^{4}$ The catalogues were created based on textual analyses, which were also computer-generated. Through them, P. Scherhaufer and his colleagues most likely counted the frequency of occurrence of certain words, which they considered to be key for the creation of future performances. Thus, they created the basic pools - catalogues, which became elements of the future script, and using these, they generated '... the possible structures of the future scripts' (SCHERHAUFER 1996: 174). Scherhaufer's best practice

2 According to the information printed on the first page of the issue in 1988.

3 The first request of the audience was met in PROJEKT 85 [PROJECT 85].

4 Author's comment: these are not available in the Goose on a String Theatre archive. 


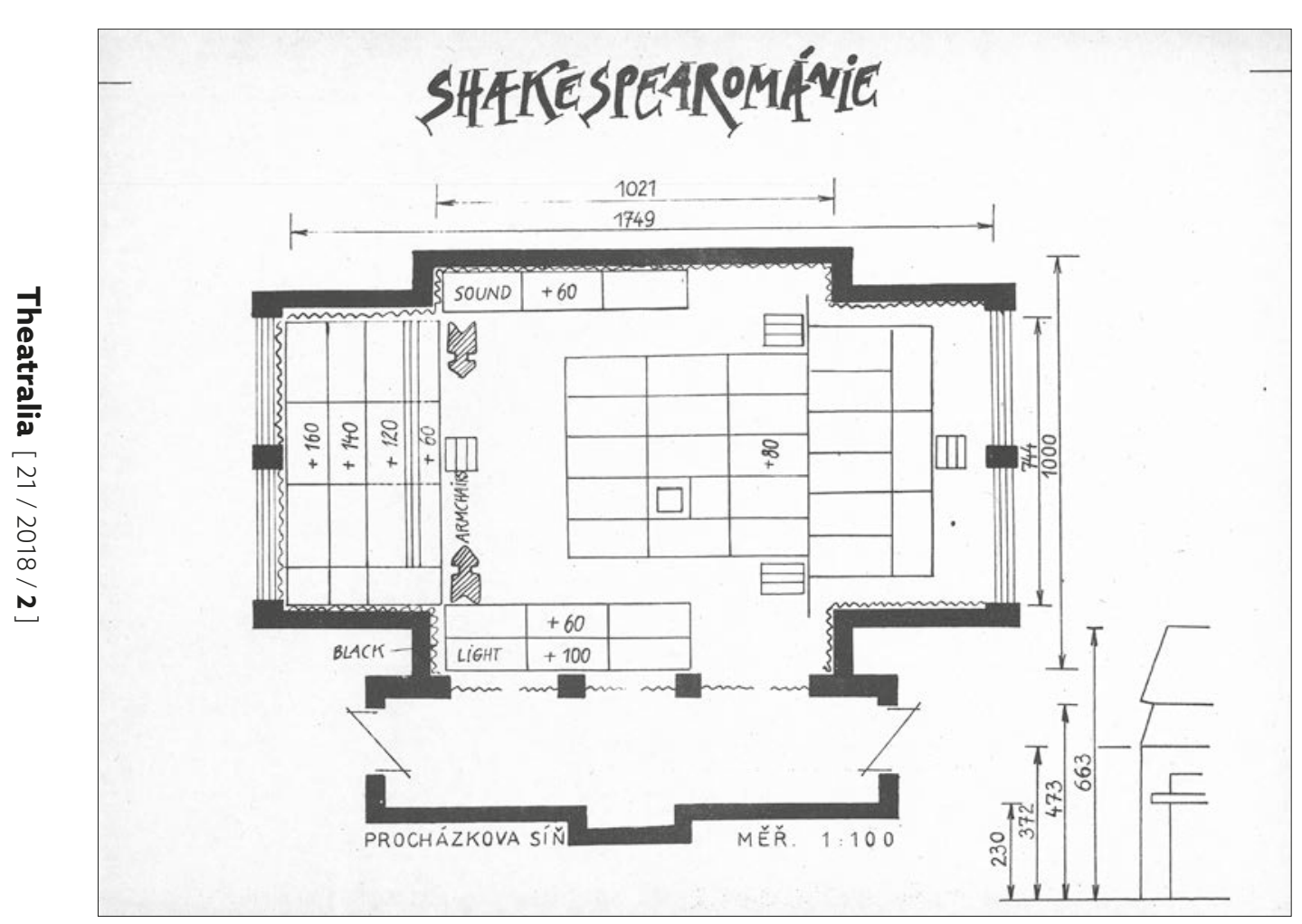

Fig. 1: Ground Plan of SHAKESPEAROMÁNIE, stage designer: David Cajtlman. Archive of Goose on a String Theatre, Brno.

was to prepare for the project consistently. In the 'fuelling' phase, ${ }^{5}$ he managed to collect a significant amount of material on Shakespeare and his era and materials from other areas, which helped him understand Shakespeare and his creations. However, only his dramatic texts were considered by means of spatial analysis. On another occasion, P. Scherhaufer considered the following words to be key when analyzing types of space: '... architectural, personal, state, aerated, imaginary, mental, open, empty, endless, dangerous, limited, military, coloured, physical, mathematical, philosophical, creative, invisible, everyday, relative, luminous, olfactory, Euclidean, divine, chaotic...' (SCHERHAUFER 1988: 7). In the context of visual properties of the dramatic texts, he also addressed the structure of human spatialisation, which stands on the concepts such as '... centre, vertical axis, horizontal plane, front, rear, (...) man on the road, loss of direction, volatility of human contact, paths, travel, roads, lack of direction and timelessness...' (SCHERHAUFER 1988: 9). He analysed issues of space mainly in the methodology dedicated to theatrical plays and productions in irregular

5 The so called 'fueling phase' is a research method based on continuous and unflagging reading, analysing and evaluating of the large amount of study materials. The work on the production began only after this stage of 'fuelling' was over. 
spaces undertaken in his publication entitled Stage Design in Irregular Spaces. The publication was published in 1988, and it also includes a record of the workshop titled Stage Design in Irregular Spaces, which P. Scherhaufer carried out together with the set designer Ján Zavarský in Prague on 26.-27. 4. 1986. During the workshop, the participants worked with various cataloguing criteria, to which they associated specific terms based on the analyses of drama texts. Gogol's play The Government Inspector served as a basic foundation for the workshop.

Scherhaufer established the following criteria for space (SCHERHAUFER 1988: 6061):

- according to physical characteristics (mass, dimension, time): for example physical, empty, endless, etc.

- feelings: extraordinary, imaginary

- concrete $\mathrm{x}$ abstract

- mathematical

- architectural

- etc.

We can assume that P. Scherhaufer used the above methodology to verify only one of the ways spatial analysis of dramatic texts can be performed. ${ }^{6}$ Subsequently, he probably continued in the development of this method and constantly verified its functionality for the creation of a theatrical performance. Spatial analysis, together with other types of analyses, which he constantly used or developed within the heuristic preparation phase of the productions - the so-called fuelling - is a breakthrough achievement in Scherhaufer's work. Thanks to the concept of 'irregular dramaturgy', ${ }^{7}$ these analyses enabled him to join the seemingly incongruous and cross the boundaries of impossiblity. He could stage any literary work in any space, he could 'theatrise' any everyday object, and he shunned no topics (INŠTITORISOVÁ 2006: 16). Many of his working methods are used to date by the amateur actor workshop attendants and his professional colleagues. It was thanks to them that he could carry out numerous international projects, which made him famous around Europe, such as VESNA NÁRODOV-WIOSNA LUDÓW (1980), MIR CARAVANE-KARAVAN MIR (1989) and others.

6 In his methodology, he provides examples of other types of textual analysis from the perspective of irregularities or staging (SCHERHAUFER 1988: 61).

$7 \quad$ P. Scherhaufer considers irregularity to be an inevitable condition for a relatively independent existence, momentum and development of all forms of theatre. At the same time, it is also one of the properties of space, which can be regular and irregular, and in stage design, this conflict is overcome (SCHERHAUFER 1988: 12). This dialectical understanding of stage design in irregular spaces is part of the programming standpoints of the Goose on a String Theatre in Brno, which is also known for its 'irregular' dramaturgy. Petr Oslzlý, a dramaturg and long-term collaborator of P. Scherhaufer, characterised it as follows: 'In the Goose on a String Theatre, or in any other similar type of theater, dramaturgy is not more or less isolated and a rather literary than theatrical sphere, but it is present in all the components it creates (...) Not only does it involve the dramaturgs and directors, but it is made by the whole theater because it forms its basic principles and standpoints.' (OSLZLÝ 2010: 599). It was initiated by Bořivoj Srba, a teacher of the founding members of the theater and its former dramaturg. The irregularity principle is sometimes also seen as a principle of uniqueness, especially in the context of the then established theatre aesthetics. 
Within the framework of preparations for the SHAKESPEAROMÁNIE project, Scherhaufer used computer analysis to consider the visual elements in Shakespeares's sonnets, for example, he found that almost $1 / 3$ of the words they contain are somehow connected to space. ${ }^{8}$

Surprisingly, he also found that:

a) Shakespeare's first twelve comedies and the so-called history plays mostly deal with what is above, as evidenced by the concepts such as heaven, space, clouds, sun, air, tree-tops, kings and the like.

b) The twelve plays around Hamlet are concerned with the word 'wall' and the expressions used are panels, paravanes, curtains, spinet, chairs, baskets, partition, secrets, intrigues and similar.

c) The last group is concerned with the expressions connected to the collapse of Shakespeare's heaven, such as depths, abysses, ditches, valleys, tombs, shores, depression, doubt, artifice and similar.

Thanks to this analysis of topics, Scherhaufer understood that it is possible to create three primary montages of the plays according to the criteria mentioned above. The following productions were created:

1. Veličenstva Blázni [Their Majesties' Fools] because the first group of plays dealt with comedy and the rule of kings and fools both in the comedies and historic plays.

2. Lidé Hamleti [The Hamlet Humans] because the second group of plays was concerned directly or indirectly with the character of Hamlet.

3. Člověk bouř [The Tempest Man] because the last group of plays tackled the enormous power of human beings in their unusual situations, namely King Lear and The Tempest.

From time to time, P. Scherhaufer validated his scripting processes in amateur theatre groups, ${ }^{9}$ for example, the graduates of his Director course in Slovakia, organised by the National Centre of Culture and Further Education in Bratislava, created several scripts with his methods. ${ }^{10}$ Scherhaufer's first official interaction with Shakespeare was in 1987 when he and his colleagues (probably) held the workshop called Shalespeare's Theatrum Mundi in Österreichischer Bundesverband Brixen.

Scherhaufer also studied numerous academic texts in the field of proxemics, humanistic geography, and personal experiments of other theatre professionals such as

8 He was inspired by an experiment of the Russian poet Viktor Arkadyevich Bely who analysed colour in the works by Nikolai Vasilyevich Gogol.

9 Under Socialism, it was common for professional directors to try things out or experiment in an amateur theatre environment. At times, they would create artistically more valuable or more daring theatre than professional theatre.

10 Petr Scherhaufer makes the connection here to the conferences organized by the Czech Association of Amateur Theatre Makers in Hronov and Děčín (SCHERHAUFER 1996: 174). 


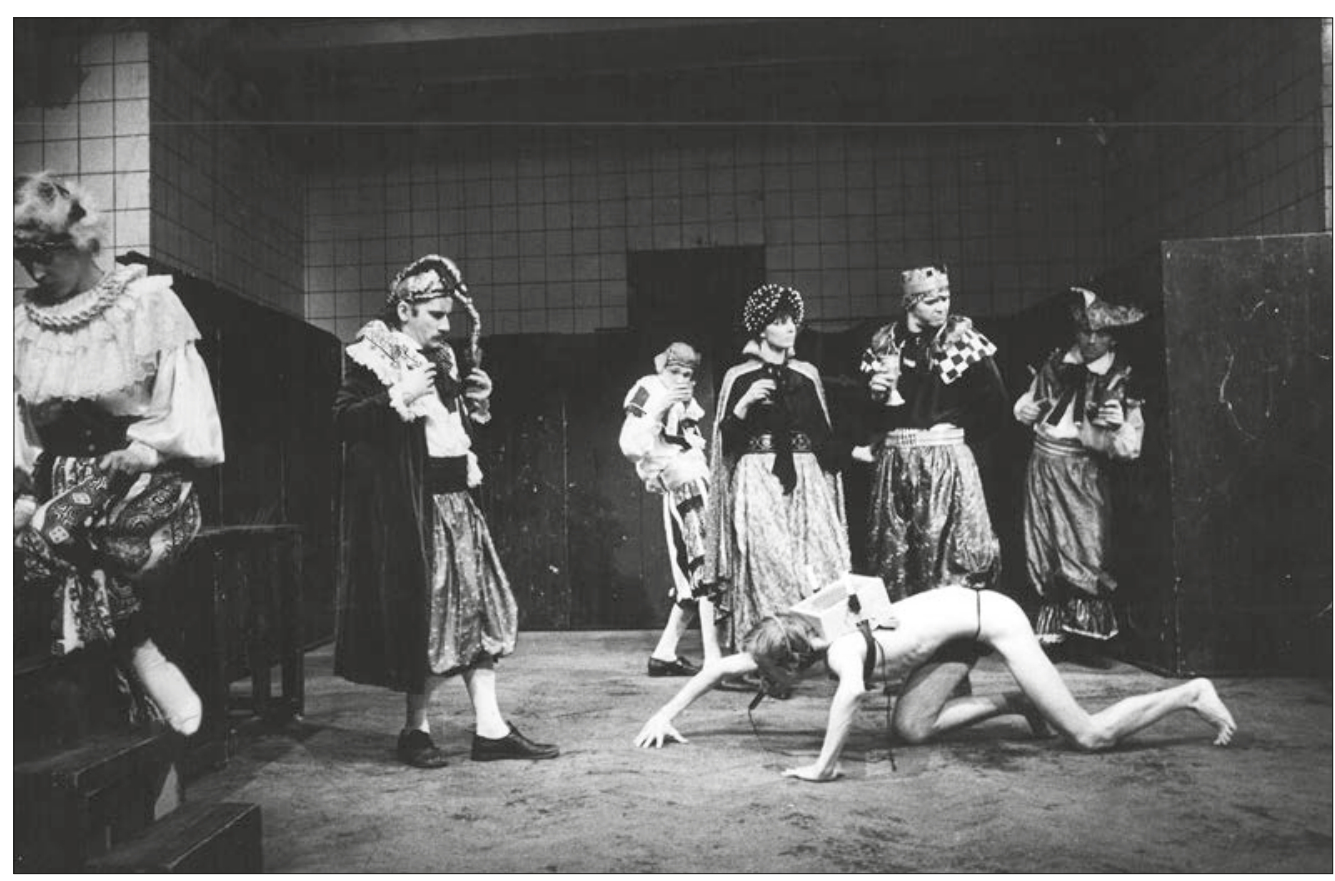

Fig. 2: The Hamlet Humans. Foto Jiři Dvořák. Archive of Goose on a String Theatre, Brno.

Giorgio Strehler, or a two-day project of Peter Stein titled Shakespeare Eiland. Due to the systematic logistics of his project, Scherhaufer saw Peter Brook's Mahabharata three times (once from backstage) (SCHERHAUFER 1996: 176-177).

SHAKESPEAROMÁNIE [the Shakespearomania Trilogy] had a quite tricky inner life. There was a significant fluctuation of actors in some of the productions, which consequently influenced the overall expression and meaning. Petra Kohutová (1991: 69) recollects of the production of Veličenstva Blázni [Their Majesties' Fools]:

The production run was significantly shortened - from three hours to two. (...) The first version was impressive thanks to the acting of Miroslav Donutil - especially the initial seduction scene of Richard III. And Queen Anne. (...) When Donutil left for the National Theatre, the act was shortened, and Donutil was replaced by I. Urbánek - a less convincing actor.

She also stated that Slovak gradually replaced some exchanges in the balcony scene, which was in Czech in the first version. The reason for this was the demand for a more emotional atmosphere, which was easier to achieve in Slovak as it is considered softer than Czech.

The project was only launched partially and not fully as per the original intention. The entire cycle, i.e. all three parts, one after the other in a single day, was first presented as late as in 1991 in Bratislava and in 1993 in Brno. In 1993, it was also performed at the International Theatre Festival in Stuttgart. (SCHERHAUFER 1996: 177-178) 


\section{Postmodern Intertextuality as a Key to Stage Design}

Using his direction style, Peter Scherhaufer continued in the process of eliminating the taboo connected with creating a dramatic piece and using purely theatrical elements. He continued in the simplification of making a dramatic piece by a group of authors. His approach (and the approach of the whole team) continuously disrupted the pervasive dominance of notions of the indispensability of linear and realistic interpretation in dramatic productions, and equally the use of conventions stemming out of psychological realism. Another essential attribute of Scherhaufer's style is the fact that he used intertextual links, various forms of metatextual links, such as symbols of other kinds, and worked with multiple backgrounds in terms of textual material. He also used citations or different links to other works of art and drama pieces and non-theatrical realities such as allusion, persiflage, palimpsest, parody, travesty, pastiche, satire etc. This type of linkage also applies to stage design. The project SHAKESPEROMÁNIE [the Shakespearomania Trilogy] is a typical postmodern ${ }^{11}$ intertextual project (INŠTITORISOVÁ 2006: 18). Various types of links were used in all of its productions. Production always depends on the script and the way the actors work with it on stage, but the three productions were interconnected also through scenography and acting (etc.).

Let us have a look at the productions one by one from this perspective:

\section{William Shakespeare: Veličenstva Blázni - Shakespearománie I [Their Majesties' Fools - Shakespearomania Trilogy I]}

(Plays: Sen noci svatojánské [A Midsummer Night's Dream], Romeo a Julie [Romeo and Juliet], Richard III. [Richard III], Večer třikrálový [Twelfth Night], Král Jindřich IV. (díl I. a II.) [Henry IV (parts I and II), Král Jindřich VI. (díl II.) [Henry VI (part II), Král Jan [King John], Richard II. [Richard II])

Translation: Jiří Josek, Antonín Klášterský, Milan Lukeš, Antonín Přidal, Václav Renč, Zdeněk Urbánek, Jan Werich

Script: Petr Oslzlý, Peter Scherhaufer

Dramaturgy: Petr Oslzlý

Dramaturgic cooperation: Karel Král

Stage: David Cajthaml

Costumes: Jana Zbořilová

Music: Zdeněk Kluka a Progres 2

Goose on a String Theatre in Brno, Procházka Hall, House of Arts in Brno, premiere 26. 3. 1988.

According to Scherhaufer, the staging intention was to show: '...that in their madness, the Majesties in power do not see, or do not want to see, the world as it is and the people on

11 Scherhaufer also showed his affiliation to postmodernism in the theatre programme Člověk bouř [The Tempest Man]. 
the other side of the power spectrum...' (SCHERHAUFER 1996: 176), and the creators viewed them as '...real Majesties in their madness' (SCHERHAUFER 1996: 176).

The basic scenographic outline of the stage was the same for all the productions at Procházka Hall in The House of Arts in Brno; the only thing that changed were the stage props and the way they were used.

Since the most frequently used words had to do with height, heaven, clouds, etc., the stage was located in an elevated position; it was a Shakespearean type of stage (i.e. the shape of the stage allusively resembled the original) and it was surrounded by audience sitting on all three sides. The characters, mainly the fairies, came on the stage from the stage floor. There were three curtains in the background. The first was blue, and after the initial act of Oberon and Titania, the curtain was lifted up like a heavenly arch. The second one was red, and it was devoted to the acts of fools and Majesties. The last one was a black net, which represented an imaginary or real jail. Everything was enclosed in a space with white tiles that looked like a torture room or a place of execution. There was a dominant tall throne in the middle of the space (KOHUTOVÁ 1991: 65-69). The contests among the 'Majesties', such as Richard III, Henry V and others, were always the same - fist fights, or sword fights and so on. The matches were held in slow motion (parody). The winner always won the same crown, and the way the crown was put on the head of the winner was different each time. It was too big for Richard II, so it kept falling on his neck, it covered Richard III eyes (lampoon) etc.

For example, the acting of Malvolio ${ }^{12}$ (the future Richard II) played by Pavol Zatloukal, showed the use of some more basic interlinking devices woven through the project:

- The bush used as a hiding place for the characters in this part of the project was also used to represent plagiarism in the other parts of the project;

- The costumes were a combination of historical attire (even using recognisable theatre costumes) and contemporary clothing, therefore we are talking about pastiche;

- Introducing comedy into the underlying meaning of the red curtain - which equates to travesty.

\section{William Shakespeare: Lidé Hamleti - Shakespearománie II [The Hamlet Humans - The Shakespearomania Trilogy II]}

(A montage of translations of Hamlet).

Translation: Milan Lukeš, Zdeněk Urbánek, using sections from Much Ado About Nothing and Troilus and Cressida

Script: Peter Scherhaufer, Karel Král

Dramaturgy: Petr Oslzlý, Karel Král

Set Design: Miloň Kališ

Costumes: Růžena Tomková

Music: Zdeněk Kluka and parts of Vivaldi's Four Seasons

Goose on a String Theatre in Brno, Procházka Hall, House of Arts, Brno, premiere 20. 12. 1990.

12 The act begins at $42 \mathrm{~min} 50 \mathrm{sec}$ and ends at $45 \mathrm{~min} 35 \mathrm{sec}$. 


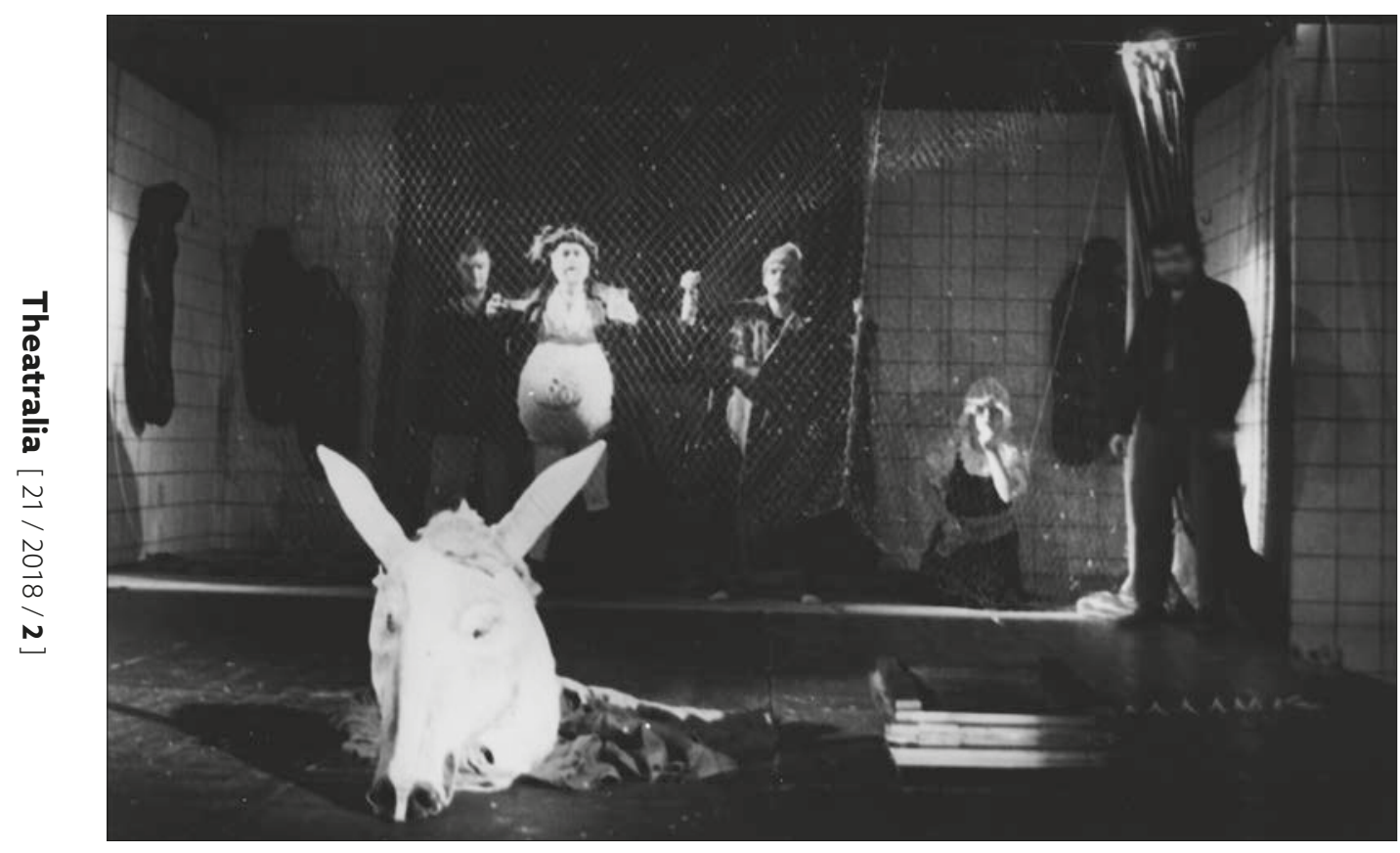

Fig. 3: Their Majesties Fools. Foto Jiří Dobrovolný. Archive of Goose on a String Theatre, Brno.

Again, according to Scherhaufer, the staging intention was to perform the play as if in the period when ... the theatre "went haywire'13. There are Hamlets everywhere, and everyone keeps asking Hamlet questions: Does it make sense to live? How should we exist in times when having means more than being? Should we rather sleep and cease to exist? (SCHERHAUFER 1996: 177).

The main stage was changed right at the beginning to a space evoking earthiness. Fortinbras' soldiers dismantled the stage while drumming; only the side walls remained with a staircase going down. The scene was filled with sand and surrounded by walls - the walls were black, and the characters could move behind them. Such an arrangement turned the stage into an arena. Hamlet (or the Hamlets) wrote on the walls from time to time with white chalk, but the main title was: The era unhinged.

Intertextual montage, palimpsest (multiplication of a character by several actors) and citations were some of the most often used approaches in this production:

- Hamlet dies in the first act and utters six sentences - a montage of various other exchanges used later in the production and sometimes in very different situations:

- Hamlet is played by four actors, Ophelia by three actresses, Gertrude by two actresses:

13 Scherhaufer's term, theatre in a fast-changing society, during a revolution or in an era of major shifts in the society. Free translation by Z. K. 
- A scene with sunbathing and bathing is inserted, the Royals are dressed up in contemporary clothes (swimsuits, bathrobe, sunglasses etc.),

- Mad Hamlet enters the 'arena' almost naked, with a typical Socialist radio receiver attached to his back, so he becomes the broadcasting medium of the dead spirit (his father);

- Polonius was murdered four times - not only by Hamlet but also by his friends and even the Queen whose hand was steered by Hamlet.

- The whole story is narrated by Horatio who looks like a failed intellectual, and he finishes the play with puppetry (thereby creating a threefold theatre interpretation, Shakespeare's play is represented by enormous 'mannequin-puppets'). Horatio uses the translations of Milan Lukeš and Zdeněk Urbánek to deliver the same monologue on what 'he is going to talk about';

- The costumes are a combination of folk, contemporary and historical costumes.

The production is characteristic of metaphorical use of language. For example, the gravedigger act is the only time when the 'wall' comes down even deeper. ${ }^{14}$ The gravedigger digs a hole into the stage, and he keeps tossing out 'human remains' such as a shoe, umbrella, and similar objects. After Ophelia's funeral, the tomb is ceremonially taken away by Fortinbras' soldiers.

\section{William Shakespeare: Člověk Bouře - SHAKESPEAROMÁNIE III [The Tempest Man - The Shakespearomania Trilogy III]}

(Plays: Král Lear [King Lear], Macbeth [Macbeth], Zimní pohádka [The Winter's Tale], Bouře [The Tempest])

Translation: Milan Lukeš, Ludvík Kundera

Script: Peter Scherhaufer

Dramaturgy: Petr Oslzlý

Production: Miloš Karásek

Music: Zdeněk Kluka

Goose on a String Theatre in Brno, premiere 23. 10. 1993

Again, according to Scherhaufer, the staging intention was to portray the world of the tempest man, that is:

... saturated by the postmodern 'awareness of an irretrievable loss of wholesomeness' when 'the meaning of culture is essentially economic' and taste is a matter of 'cultural marketing'. 'Market relations as part of the present context of communication determine not only the reproduction and distribution of activities, but through them also the creation of artwork' and 'typical elements of art' are citations, plagiarism, travesty and pastiche. (SCHERHAUFER 1993) 
The stage was arranged differently this time. When King Lear found out about the betrayal of his daughters, he destroyed the side walls of his 'kingdom' - the walls covered with white tiles. He only left the back wall. In front of the back wall, Lear became aware of his helplessness and the mistakes he made. The division of the kingdom among the three daughters had an interesting scenographic solution - each of them tore part of their father's coat. The death of Lear was also theatrically functional. He died in an armchair - the throne that was later taken by Macbeth - he is led by Lady Macbeth in the photograph, and his empty throne became part of his hallucinations.

Some interesting intertextual links:

- During the storm, the witches from Macbeth enter Lear's hallucinations (palimpsest),

- Hamlet passed from the right side to the left side with the radio and candles on his back (citation),

- The scenography also included an enormous golden face - a mask representing a Major General (allusion to the present),

- The costumes are a combination of theatre-evocative clothes (for example the Clown wears a Harlequin outfit), historical and contemporary attire.

The act in which Lear becomes Prospero after his funeral and his throne is passed on to Macbeth is an example of how the environment changes from one Shakespeare's play to another. ${ }^{15}$

\section{Conclusion}

The project fulfilled Scherhaufer's ideas and the ideas of the entire Goose on a String Theatre regarding the positives of theatre productions in non-standard spaces, with non-standard dramaturgy, direction etc., or spaces 'other' than the ones commonly used at that time. The programming scope of the Goose on a String Theatre states:

The concept of Goose on a String Theatre stems out of the idea of the theatre as a cultural centre (...). We understand dramaturgical shift as the use of standard and non-standard texts, adaptations, literal propositions, scripts, scenarios, montages and dramatisations, hoping to find inspiration through such an approach... (SRBA 2010: 163).

The real importance of SHAKESPEAROMÁNIE, however, is manifold. The project is not 'only' an important internal theatre initiative that uses irregular stage design, irregular dramaturgy, etc. at the Goose on a String Theatre:

15 This act begins at $1 \mathrm{hr} .26 \mathrm{~min}$ and ends at $1 \mathrm{hr} .27 \mathrm{~min} .30 \mathrm{sec}$. 


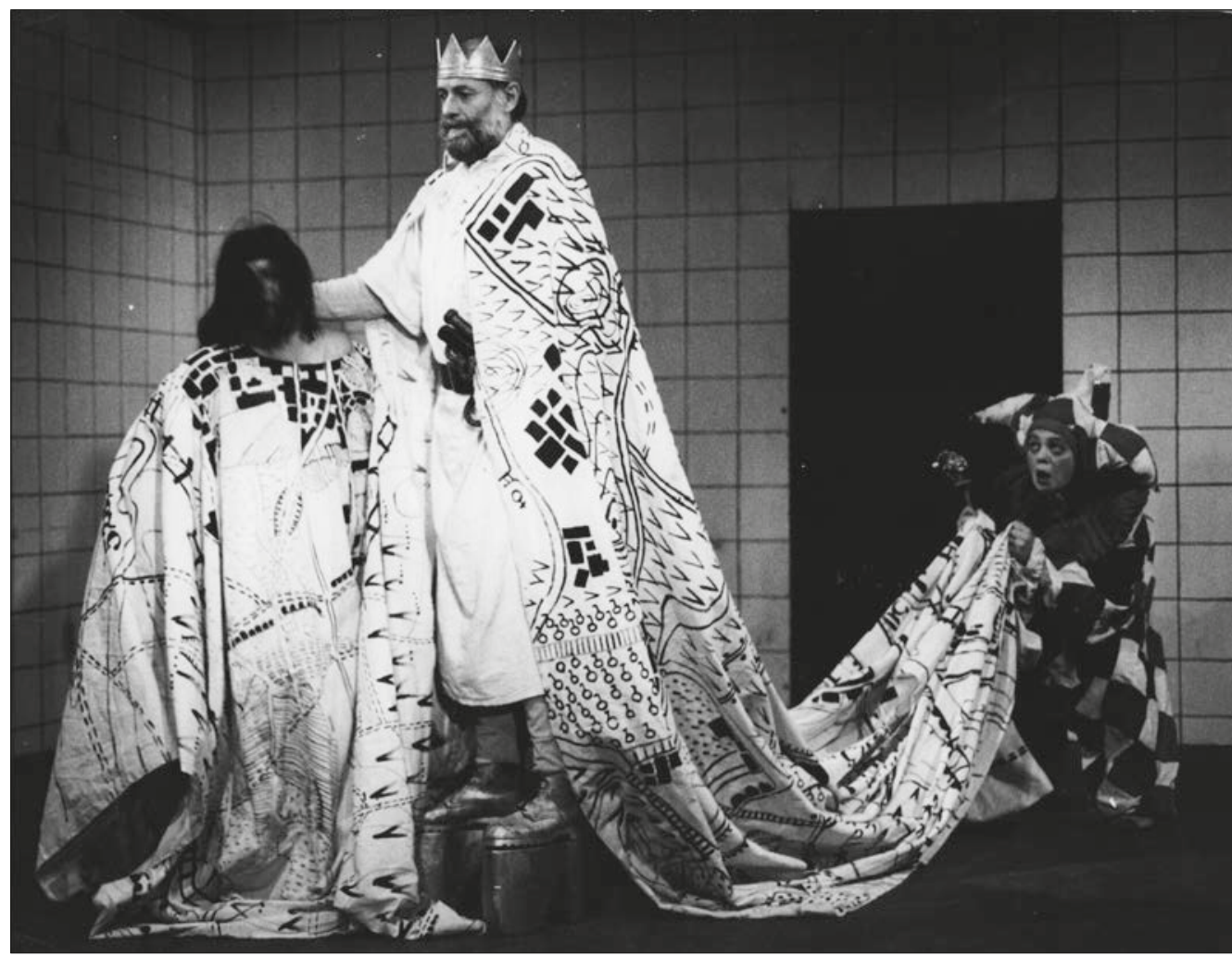

Fig. 4: A Man Tempest. Foto Jef Kratochvil. Archive of Goose on a String Theatre, Brno.

1) Since the launch of SHAKESPEAROMÁNII [the Shakespearomania Trilogy] and throughout its ten years of existence, we haven't noticed a similar project in the Czech Republic or Slovakia. However, there were many productions that use montage or allusion or other postmodern approaches to Shakespeare's texts.

2) The project is an example of work in progress, a highly acclaimed modern form, because, according to P. Oslzlý, the project remained '...a work in the making' until the very end, a completely open creative process that could be rethought and reshaped time and time again. The project allows its authors and the whole theatre ensemble to learn and use their experience (OSLZLÝ and SCHERHAUFER 1988). However, a similar form was also assumed in other productions of Goose on a String Theatre or P. Scherhaufer's productions.

3) In terms of stage design, it is inspiring because the three scenographers were able to make the most out of the basic spatial layout. They opened the acting space to imagination, combined the 'old' theatre language of Shakepeare's plays with postmodern intertextual and - at the time of the project - new procedures. With each stage design solution, the same acting space always received different underlying importance. 
And precisely that is its professional message for today.

The project is above all an example and evidence of the exploratory, pedagogical and visionary efforts of P. Scherhaufer. He proved that preciseness, objectivity and a scientific approach to selected themes has a great significance in theatre. Through his methods as a director, which he noted in the description of the project, we have the opportunity to learn to this day about the possibilities in stage design by using different visual dramatic templates. Although the project was implemented in a regular theatre interior, it is an embodiment of one of the very important visions of P. Scherhaufer about the importance of irregularities in theatre, which lies in breaking the conventions. This is what Jozef Ciller, his long co-worker and stage designer, said about Scherhaufer: 'He believed that the interdisciplinary nature of work is a prerequisite for other views in realtion to theatre creations, which helps us overcome the established stereotypes of standard theatre experience. By means of sophisticated lexical logotypes, he always arrived at impressive conclusions, which fostered new solutions' (CILLER 2006: 9).

\section{Acknowledgement}

I would like to thank David Cajtlman and Jeff Kratochvil for their kind permissions to use the photographic material and illustrations.

The author has exerted all efforts to solicit the relevant permissions to publish the work of other artists. If you have any information about the holders of the respective copyright, please contact the author of this study.

\section{Bibliography}

CILLER, Jozef. 2006. Pár slov na úvod [A few words to begin with]. In Dagmar Inštitorisová and col. Peter Scherhaufer - Učitel” „šaški “ [On the Direction Style of Peter Scherhaufer]. Bratislava: Eleonóra Noterská - NM Code in cooperation with the Association Corpus, 2006: 9-10.

INŠTITORISOVÁ, Dagmar. 2006. K režijnému rukopisu Petra Scherhaufera [On the Direction Style of Peter Scherhaufer]. In Dagmar Inštitorisová and col. Peter Scherhaufer - Učitel’ „šaškü“ [Peter Scherhaufer - the Teacher of 'Clowns']. Bratislava: Eleonóra Noterská - NM Code in cooperation with the Association Corpus, 2006: 16-20.

KOHUTOVÁ, Petra. 1991. SHAKESPEAROMÁNIE. Pokus o orientaci v projektu Divadla Husa na provázku [SHAKESPEAROMANIA. An Attempt to Get Oriented in the Project of the Goose on the String Theatre]. Svět a divadlo 2 (1991): 8: 65-69.

OSLZLÝ, Petr. 1999. Divadlo Husa na provázku 1968/7-1998 (kniha v pohybu I...) [The Goose on the String Theatre 1968/7-1998 (a Book in Motion I...)]. Brno: Centre for Experimental Theatre, 1999.

OSLZLÝ, Petr. 2010. Smysl nepravidelnosti [The sense in irregularity]. In Bořivoj Srba: Vykročila husa a vzala člověka na procházku: Pojd! Založeni a prvnich pět let umělecké tvorby Mahenova nedivadla Husa na provázku [Divadla na provázku] 1967-1972. Dokumenty - memoáry - studie [The 
goose stepped out and took man for a walk: Come! The establishment and first five years of artistic creations in Mahen's non-theatre The Goose on the String [theatre on the string] 1967-1972. Documents - memoirs- studies]. Brno: Janáček Academy of Music and Performing Arts in Brno, 2010: 599-605.

SHAKESPEAROMÁNIE I. - Veličenstva blázni. 1988. (Bulletin k inscenácii) [SHAKESPEAROMANIA I. - Their Majesties Fools. 1988. (Theatre Programme)]. Brno: The Goose on the String Theatre, 1988.

SCHERHAUFER, Peter. 1993. K projektu SHAKESPEAROMÁNIE I-III [On the Project of Shakespearomania I-III] In SHAKESPEAROMÁNIE I.-III. (Theatre Programme). Brno: Goose on the String Theatre, 1993.

SCHERHAUFER, Peter. 1996. SHAKESPEAROMÁNIA. K projektu Shakespearománie [SHAKESPEAROMANIA. On the Project of Shakespearomania]. In SCHERHAUFER, Peter. Divadelné projekty Divadla Husa na provázku [Theatre Projects of the Project Goose on the String Theatre]. Bratislava: The National Centre of Culture and Further Education, 1996: 173-178.

SCHERHAUFER, Peter. 1988. Inscenování v nepravidelném prostoru [Stage Design in Irregular Spaces]. Brno - Ostrava: Regional Cultural Center, Karviná County Cultural Center, 1988.

SRBA, Bořivoj. 2010. Vykročila husa a vzala člověka na procházku: Pojd!' [A Goose Stepped Out and Took a Man Out for a Walk]. Brno: Janáček Academy of Music and Performing Arts in Brno, 2010.

\section{Prof. PhDr. Dagmar Inštitorisová, PhD.}

Department of Mass Media Communication and Advertisement, Faculty of Arts, Constantine the Philosopher University in Nitra, Slovakia dagmar.institorisova@gmail.com

Dagmar Inštitorisová (1961) - graduated in Theory of Culture at the Department of Aesthetics and Science of Art, Faculty of Arts, Comenius University in Bratislava in 1983. She specialises in history and theory of drama and specifically deals with the theory and history of interpretation of theatre, contemporary Slovak theatre, theatre criticism and semiotics. She wrote a number of academic monographs, edited and co-authored collective monographs and volumes, and she also writes fairy tales. She publishes both in Slovakia and abroad. She is a member of various academic communities (Independent Writers Club, Slovak Association of the Club of Rome, AICT, Association of Theatre Critics and Researchers, Czech Association for Theatre Research, Slovak Association for Theatre Research). She was head of the ESF project with focus on educating students through drama from 2010 to 2014, which helped publish forty-five publications, twenty-seven workshops and many other educational drama-based activities. For more information about the project, see: www.vzdelavaniedivadlom.ukf.sk. She is currently affiliated with the Department of Mass Media Communication and Advertisement, Faculty of Arts, Constantine the Philosopher University in Nitra. 